\title{
A Pragmatic Analysis on Vague Language Used in Disaster News Articles on Thejakartapost.com
}

\author{
Jaufillaili Jaufillaili, ${ }^{*}$ Riska Nurmalita, $^{2}$ Endang Herawan ${ }^{3}$ \\ ${ }^{1,2}$ English Education Study Program, Faculty of Teacher Training and Education, Universitas \\ Swadaya Gunung Djati, Cirebon, Indonesia, ${ }^{3}$ Economics Education Study Program, Faculty of \\ Teacher Training and Education, Universitas Swadaya Gunung Djati, Cirebon, Indonesia
}

*) Corresponding Author

Email: fillihidayat@gmail.com

DOI: 10.18326/rgt.v14i2.185-202

Submission Track:

Received: 28-05-2021

Final Revision: 01-12-2021

Available Online: 05-12-2021

Copyright (C) 2021 Author(s)

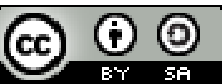

This work is licensed under a Creative Commons Attribution-ShareAlike 4.0 International License.

\begin{abstract}
This paper presents the findings analysis of categories and functions on vague language used in disaster news articles on Thejakartapost.com based on the theory of Channell (1994). In the journalism context, especially in disaster news articles, the information often contains vague language that has imprecise statements since it is harmful. Therefore, to avoid wrong statements, the reporters often use vague language in presenting information accurately. The study employed a qualitative descriptive method. A number of 24 news articles formed the data. A total of 12 news articles of natural disasters and 12 news articles of human-caused disasters were used. The period was from April 2018 to March 2019. The findings of this study showed that there were three categories of vague language, namely vague additives to numbers that were realized by approximators and adjectives. The others were vagueness of choice of vague words that were realized by nouns, and vagueness by scalar implicatures that were realized by quantifiers, numbers, and exaggerations. In addition, they also have functions of vague language. First is giving the right amount of information; it is used since the reporters just shared the right number of information although the exact number was not available. Second, filling in lexical gaps of uncertainty; it is used since the reporters wanted to cover the imprecise information with another word, and generalized word that was difficult to identify. Last but not least, self-protection. It is used since the reporters wanted to protect and hedge their statements from imprecise information.
\end{abstract}

Keywords: vague language; categories; news articles; disasters; implicature 


\section{INTRODUCTION}

In daily life, especially in the social context, humans need to communicate with each other. They use language as media to interact in society. By understanding the language and its meaning, people connect to each other (Handayani, 2015). In the process of communication in society, news articles are regarded as media for interaction. It means that reporters are the speakers, while the readers are the hearers. With rapid technology, people can also find out news articles from online news. According to Newman et al. (2017), online news constitutes the biggest source of information today, while printed newspapers have seen a significant drop in readership in the past decade. Languages in journalism context are supposed to be both formal and concise. The news articles should be delivered directly to the facts of social phenomenon to the readers. However, in some cases, it does not show the exact meaning because of the situation. Sometimes, reporters are unable to get all the facts immediately for one or another reason (Khalil, 2017), but they should report it quickly and with trust. Therefore, to protect them from making wrong statements, they often use vague language. Vague language is defined as words or phrases "which deliberately refer to people and things in a non-specific, imprecise way" Carter \& McCarthy (2006) as cited in Cutting (2007).

In disaster context, most information is about the number of events that do without strict accuracy, such as the imprecise number of people who have died or number of buildings destroyed. In this context, the reporters often use vague language since the specific information is not available immediately or it is not being reported. Therefore, the writer is motivated to analyse vague language in popular English newspaper online in Indonesia, it is called by Thejakartapost.com with the topic disasters, and it can be natural disaster or human-caused disaster.

The research conducted by Pan (2012), entitled "An Analysis of Vagueness in English News from Grice's Cooperative Principles," focuses on analysing certain samples selected from some English newspapers. The researcher used a qualitative descriptive method in analysing the data. She applied Grice's cooperative principle in analysing several samples selected from some English newspapers to show that vague language can effectively stand out the accuracy 
of the English newspaper. The writer also used three types of vague language; there were hedges, vague words, and vague implicature. The findings from this research were vague language in news usually violated the maxim of quality, quantity, manner, and relevance due to different situations, and the use of vague language promote the expressive effects of the news item and give readers a lot of things to think and meditate.

The other research study by from Khalil (2017), entitled "A Pragmatic Analysis of Vague Language in the News Articles on the Iraqi Security Crisis, investigates and pragmatically analyses the vague language in news articles on the Iraqi security crisis in the period after April 2014 when ISIS conquered important Iraqi cities. Theory of Grice's cooperative principle was used to uncover the purposes vague language serves and its effects on news articles. The researcher used a qualitative descriptive method in analysing the data. All the data were eight articles downloaded from different broadcasting corporations on Internet resources. The researcher also used three types of vague language based on Channell's theory. The most frequently used type of vague language in the research was hedging, and often flouted the maxim of quantity and manner. This research also had logical purposes that have had positive effects on the communicative aspect of the text. Therefore, in the result, the writer said that from the pragmatic perspective, there seems to be a contradiction between vague language and Grice's cooperative principle.

The gap of my research compared to those previous ones are the object of the research and the theory used to analyse the data. The first previous researcher used random articles, and the second previous researcher used articles on Iraqi Security Crisis. Both previous researchers applied Grice's cooperative principle to analyse the data, while I use Sabet \& Zhang's vague language theory to analyse the data. The novelty of my research can be seen from the findings that there are only three functions of vague language in natural disaster articles. The writer hopes that the finding of this research could contribute theoretically about the functions of vague language, especially in natural disaster articles to the pragmatic study. 


\section{LITERATURE REVIEW}

\section{Vague language}

Vague language is defined as words or phrases "which deliberately refer to people and things in a non-specific, imprecise way" Carter \& McCarthy (2006) as cited in Cutting (2007). From Carter \& McCarthy's point of view, vague language is confined to the lexical level as they regard vague language as imprecise words or phrases. According to Channell (1994) as cited in Bajri (2016), the expression or word is vague if (a) it can be contrasted with another word or expression that appears to render the same propositions; (b) it is purposely and unabashedly vague; and (c) its meaning arises from the intrinsic uncertainty. Channell argues that vagueness occurs under one of the circumstances in which an expression purposely and unabashedly is made vague. Van Deemter (2010) as cited in Zhang (2011) states that vagueness is all about the meaning and function of language. Jaufillaili et al. (2017) state that vague language is described as something that is implied without being clearly stated. Both participants know the message of the conversation though it is hidden or is not being clearly stated.

From the explanations of vague language above, it has not been clearly defined yet. Many experts have defined what vague language is in their point of view. In news article, reporters should report articles immediately, but they just have a short time. In this case, they do not know the specific information. Thus to avoid non-specific and imprecise information, they often use vague language to present information accurately. Vague language, therefore, in the writer's point of view for this research is a word or a phrase that shows an imprecise number of things, people, or other information with various functions contextually.

Channell (1994) distinguishes three types of vague language, namely (1) vague additives to numbers, (2) vagueness by choice of vague words, and (3) vagueness by scalar implicature. Vague additives to numbers are a word or phrase added to a precise figure to signal a vague reading such as "approximators." Approximators are used to refer vaguely to amounts, times, dates, and refer vaguely to factual information, in case: (around, about, nearly, round, and approximately). Besides approximators, vague additives to numbers 
are also realized by adjectives as stated by Wahyuningsih (2014), such as more than or less than.

Vagueness by choice of vague word can be defined as vague noun or reference used to refer to entities, in case: (noun: things, something, anything, what is name).

The last category is vagueness by scalar implicature; it can be defined as an exact number or plural numbers name to have a vague meaning or round number used without strict accuracy, such as "quantifiers." In case: (most, many, some, few, little, often sometimes, occasionally, seldom). A scalar implicature also can be defined as an additional meaning of the negative of any value higher on the scale than the one uttered (Yule, 1996, p.134), such as exaggeration. Therefore, vagueness by scalar implicature can be observed by exact or plural number by numbers (50 to 70,85 or 90 ), quantifiers (many, some), or exaggerations (thousands of, hundreds of).

Some of the functions above use in spoken context and sometimes in informal situation such as creating informality and atmosphere, deliberately withholding information, using language persuasively, dealing with displacement, and providing power and politeness. They are often found in spoken context such as in daily conversation. In addition, the function of covering lack of specific information, it seems suitable to the functions in news articles area but if it is seen deeply, it will focus more on spoken context. It is used if someone does not know the specific information, then they want to convey it to others. They will cover the lack of information spontaneously as in conversation. Thus, this function is not appropriate in news articles, especially in disaster areas, since it does not do spontaneously in writing news articles.

The writer in this research uses three functions of vague language, there are: (1) Giving the right amount of information. No need to be precise, just right information, and (2) Filling in lexical gaps of uncertainty (Channell, 1994). It is used for covering notions which are difficult to identify or attempts at generalisations (Urbanova, 1999). Therefore, in news article, it can be used for filling in lexical gaps of uncertainty (various things like that, something of that short, etc.). The use of self-protection has two function: To protect self against being proven wrong later, Channell (1994) and hedging the statements Wahyuningsih (2014). 


\section{Disaster}

Disaster is a situation where the damaged consequences of natural or human-caused forces make a certain region or society fulfil the request for their health care (American College of Emergency Physicians, 2012 as cited in Ozturk Tasci \& Oguz Unver, 2017). According to Bakema et al. (2018), disaster can roughly be divided into two groups. First is a study on natural disasters and human-caused disasters. Based on the definitions above, disasters are generally found to arise from two sources: 1) natural disasters, it is the process of natural disaster is natural phenomenon or caused by naturally. For instances, earthquakes, lightning strikes, and volcanic eruptions, 2) Human-caused disasters, which are caused by humans in relation to various activities of people. It does not have a cause and effect relationship with nature, and they occur due directly to human influence, (Pinar \& Adnan, 2017). For instances forest firecaused by humans, any kind of accidents and wars are considered to be humancaused disasters.

People do not always or even usually say what they mean. Speakers frequently mean much more than their words convey. For example, one might say: It's hot in here! , but what they mean is: Please open the window! or Is it alright if I open the window? or You're wasting electricity! People can mean something quite different from what their words say, or even just the opposite. For instance, to someone who has borrowed my car for the weekend and returned it with no petrol in the tank, I might say: It was nice of you to fill the car up! Alternatively, What a shame you couldn't find the petrol tank! (Thomas, 1995, p.1).

In line with the explanation above, Thomas (1995, p.1) says that there are several interesting questions arise from these observations: if speakers regularly mean something other than what they say, how is it that people manage (as on the whole they do) to understand one another? If a single group of words such as It's hot in here! could mean so many different things at different times, how do we work out what it really means on one specific occasion? Moreover, why don't people just say what they mean? These, and many other issues, are addressed within the area of linguistics known as 
pragmatics. Wray et al. (1998, p.115) say that pragmatics deals with the hidden messages.

When we read an article, pragmatics also play an important role. Readers will have various perceptions by reading the article. Therefore, context is an essential thing in writing an article. Authors often put hidden meanings in articles to be conveyed by the readers even sometimes without being clearly stated.

Based on the above reasons, this study pragmatically analyses categories and functions on vague language used in disaster news articles on Thejakartapost.com. Therefore, the following questions are discussed in this article: (1) What categories of vague language are used in disaster news articles on Thejakartapost.com and (2) What are the functions of vague language used in disaster news articles on Thejakartapost.com?

\section{RESEARCH METHODS}

To achieve the purpose of this study, the writer conducted a qualitative approach. Cresswell (2009, p.4) defines a qualitative approach as:

A means for exploring and understanding the meaning ascribe to social or human problems. The process of research involves emerging questions and procedures; collecting data in the participants' setting; analysing the data inductively, building from particular to general themes; and making interpretations of the meaning of data. The final written report has a flexible writing structure.

Since this study was a literature review, the writer used descriptive qualitative research. The goal of qualitative descriptive studies is a comprehensive summarization of specific events those in everyday terms Lambert and Lambert (2012).

The writer used selected disaster news articles with the period between April 2018 and March 2019. It can be natural disasters or human-caused disasters. The writer obtained the data from one of the most popular online newspapers in Indonesia-Thejakartapost.com. Each month, the writer took one sample of natural disaster, and one sample of human-caused disaster. The reason of limitation of this period because there were many disaster incidents, such as tsunamis, earthquakes, landslides, volcanic eruptions, bombs, plane 
crashes, train or car accidents, explosions, etc. The writer also wanted to know how often the reporters used vague language in their articles in a one-year period.

There were several steps that the writer used to collect the data: (1) Searching and collecting process, (2) selecting process, (3) downloading process. The writer searched and collected news articles about the topic 'disaster' on Thejakartapost.com. The writer also observed the articles one by one whether there were categories of vague language or not. The period was between April 2018 and March 2019. The next process was selecting process. The writer chose one disaster news, and one human-caused disaster news in each month on Thejakartapost.com as the writer's data. After the process of selecting news articles, the writer downloaded the articles on Thejakartapost.com website. The writer downloaded the selected news articles from the website http://www.thejakartapost.com/news.

According to Miles et al. (2014), there were three steps of data analysis, namely: 1) data condensation, 2) data display, and 3) drawing conclusion. After collected the data, the first step was data condensation the writer read and understood carefully the selected news articles. The next step was finding categories of vague language based on Channell's theory. In the analysis process, the writer collected sentences that contained vague language into table in each source. Subsequently, the writer put numbers of data and codes of data in each sentence. Then, the writer continued to write the categories of vague language in each sentence. Therefore, it could answer the first formulation of the problem "what categories of vague language are used in disaster news articles on Thejakartapost.com?" The second step was explaining the functions of vague language in each sentence that contained vague language. Therefore, it could be answered the second formulation of the problem "what are the functions of vague language used in disaster news articles on Thejakartapost.com?"

The writer wrote all categories and functions in column of tables. The next step was data display. After the writer analysed each sentence that contains vague language, the next step was writing the analysis of data. The writer wrote the representative data in a form of explanation of words descriptively. As a 
result of this research, the writer made conclusions about categories and functions of vague language used in disaster news articles on Thejakartapost.com with clearly and descriptively.

\section{RESULTS AND DISCUSSION}

In the following, the data analysis was done using vague language theory based on Channell (1994) theory. The writer found 177 categories of vague languages that contained vague language from 24 news articles on Thejakartapost.com. Three types of vague language were found, namely vague additives to numbers that were realized by approximators and adjectives. The others were vagueness of choice of vague words that were realized by nouns, and vagueness by scalar implicatures that were realized by quantifiers, numbers, and exaggerations. In addition, they also have functions of vague language. First, giving the right amount of information; it used for giving the right amount of incident although it was not precise to the fact. Second, filling in lexical gaps of uncertainty; it used for covering aim which is difficult to identify or often used for generalizing. Last, self-protection; it often used to protect the statement that was unclear and to hedge the statement since for avoiding wrong information. There are some examples of data analysis:

\section{Vague Additives to Numbers}

\section{Approximations}

Sentence: At least four people were killed and another was missing in Fiji after Cyclone Josie caused severe flooding in the South Pacific island nation, local media reported.

The sentence contained a vague expression 'at least.' The vague of 'at least' could be categorized as vague additives to numbers since vague additives to numbers can be approximation such as 'at least.' The vague approximation 'at least' above referred to an uncertain number of people who were killed in Fiji after Cyclone Josie. This case showed that it was a minimum number of people who killed in Fiji after Cyclone Josie. The reporters just wrote a minimal number of "at least 4 " because of terrible situation, they could not get the exact number of all people who had been killed., but in fact, there were more than 
four people. Therefore, to avoid the wrong information, the reporter chose to use a minimum number "at least 4" to present the information accurately.

The vague Additives to numbers of approximation "at least" above could function as self-protection. It was hedging the statement of the people who killed in Fiji after Cyclone Josie. In fact, there were not only four people, but also there were more than four people who had been killed. The reporters knew there were more than four people, but they did not know how many they were exactly. In this case, they did not know the exact number, but they should give information accurately. They used 'at least' as a minimal number of people who had been killed to protect his statement. Therefore, it used to protect the reporter's statement from making mistake if the number of people were not precise to the fact.

\section{Adjectives}

Sentence: A deadly virus carried by fruit bats has killed at least five people in southern India, and more than $\mathbf{9 0}$ people are in quarantine, a top health official said Tuesday.

The sentence contained a vague adjective "more than." The adjective "more than" could be categorized as vague additives to numbers because it referred to numbers that had a vague meaning such as "more than 90 " above. In this case, the reporters did not know the specific number of people who were in quarantine because Nipah virus. In this news article, they reported only with the number 90 . In fact, there were more than 90 . It could be $91,92,93,94,95$, 96 ..., etc.

Vague additives to numbers "more than" above could function as giving the right amount of information. The reporters supplied the number of people who were in quarantine because Nipah virus. It showed that it was an uncertain number. The people not only 90 , but also there were still many people who were in quarantine. In this article, the reporters did not get the specific numbers in detail. Thus, they just gave the right numbers of information with "more than 90." They thought they just needed to share the right numbers of information to the readers, although that information did not need to be precise numbers. 


\section{Vagueness by Choice of Vague Word}

\section{Noun}

Sentence: "My family are safe but my house has been destroyed -everything's gone," said Sunaria.

The sentence contained a vague expression "everything." The word "everything" here indicated to noun. It could be categorized as vagueness by choice of vague word that deliberately referred to unclear or non-specific reference such as "everything."

In this context, the interviewee, Sun aria used "everything" to explain things that had gone. It was unclear because "everything" here referred to all his house equipment. In this case, he wanted to tell that all equipment of his house that had gone because tsunami attack, but he did not know what kind of things or equipment there. He could not mention one by one things or equipment that had gone, because there were so many things or equipment in his house. Therefore, he used vagueness by choice of vague word "everything" to avoid wrong information to the reporter. Therefore, the reporters just gave information to the reader based on the interviewee's information.

Vagueness by choice of vague word "everything" above could function as filling in lexical gaps of uncertainty. In this case, the reporters just showed all information from the interviewee to the reader about everything that had gone. It showed that the interviewee and the reporters did not know all information of everything that had gone because tsunami attacks.

Therefore, vague "everything" above replaced or filled gap of the equipment or things of his house that not exactly known by the interviewee because of terrible situation such as tsunami attack.

Therefore, the use of "everything" here is also because the interviewee and the reporter wanted to generalize all things which had gone with "everything". Therefore, it was suitable with the function of filling in lexical gaps of uncertainty. 


\section{Vagueness by Scalar Implicature}

\section{Quantifiers}

Sentence: Some villagers perished when the powerful tsunami struck on Saturday night, sweeping over popular beaches of southern Sumatra and the western tip of Java and inundating tourist hotels and coastal settlements.

The sentence contained a vague expression "some." "Some" in the sentence above referred to a quantifier; therefore, it can be categorized as vagueness by scalar implicature. It could be a plural number of people or things that had vague meaning, such as "some" above. In the sentence above, a quantifier, "some" referred to plural number of villagers who perished when the powerful tsunami struck. The reporters used some villagers because they did not know the exact number of villagers who perished when the powerful tsunami struck. They just knew that there were still many villagers who perished, but they were not sure how many villagers there were. Therefore, they chose to use vague expression "some" to avoid wrong information.

The vague quantifier "some" above could function as giving the right amount of information. Since this was a disaster news article, it often presented large numbers of incident. The reporters were difficult to get precise numbers. In the case above, they did not know the exact number of villagers who perished. However, they should give the right information about the number of villagers who perished when the powerful tsunami struck. Therefore, they just gave the right information, and did not need to be precise. The use of vague quantifier "some" was the best choice to give the right information about number of villagers. However, with the use of vague language of quantifiers, such as "some" above, readers can imply the meaning that some villagers referred more than one or many villagers. The reporters chose to use vague expression "some" to give accurate information to the readers rather than just presuming the numbers.

\section{Numbers}

Sentence: There were conflicting reports on the number of dead in the alleged gas attack, with the White Helmets reporting between $\underline{\mathbf{4 0} \text { and } 70}$ killed.

The sentence contained a vague expression "40 and 70'.' Thus, it referred to categories of vague language of vagueness by scalar implicature that was 
realized by number. It had plural numbers, which had a vague meaning. In the sentence above, it showed the exact and plural numbers of "40 and 70", but in fact, it was not precise. The precise number of people who died in the alleged gas attack above were not 40 or 70 , but between 40 and 70 . The reporters used '40 and 70', because they did not know the number of people who died accurately. They just knew there were at least 40 and less than 70 people who died because of the alleged gas attacks. Therefore, this vague language was suitable with categories of vagueness by scalar implicature. The numbers "40 and 70" had a vague meaning realized it.

In the case above, vagueness by scalar implicature " 40 and 70 " functions as self-protection. The reporters did not know how many people who died in the gas attack specifically. They just knew the victims were between '40 and 70 . Therefore, to avoid the wrong statement, they preferred to choose vagueness by scalar implicature "40 and 70" to protect their statement. In this vague expression, the reporters tried to protect their statement with hedging the number of people who died. They bounded the numbers were at least 40 and less than 70 people who died because of the gas attack. In fact, it can be 40,41 , $42,43,45,46,47,484950 \ldots . . .70$.

\section{Exaggerations}

Sentence: Anticipating a regime attack, thousands of people have fled the ISheld zone in the past two days heading toward the Israeli-occupied Golan Heights.

The sentence contained a vague expression "thousands of" because it referred to unspecific numbers of people. It could be categorized as vagueness by scalar implicature that was realized by exaggeration. It showed an unclear number of people who had fled the IS-held zone. The vague "thousands of" implied to exaggerate the number of people since it could be additional meaning which had a value higher numbers such as in the case above. In fact, what was reported was not precise. Therefore, the number of people who had fled could be more than thousands of people.

The vague expression "thousands of" gave the right amount of information. The reporters just shared the right number information about people who had fled the Is-held zone, although they did not give the imprecise numbers. In this case, there were so many people and it could not be counted. 
Thus, to avoid the wrong numbers, the reporters chose to use vague expression "thousands of" to share the accurate information to the readers.

\section{CONCLUSION}

Based on the data analysis, there were 177 categories of vague language that the writer found from 24 articles on Thejakartapost.com. There were three categories of vague language, namely vague additives to numbers, vagueness by choice of vague word, and vagueness by scalar implicature. First, the writer found two categories of vague additives to numbers, namely approximations, and adjectives. Second, the writer just found one category of vagueness by choice of vague word, namely nouns. Last, the writer found three categories of vagueness by scalar implicature, namely quantifiers, exaggerations, and numbers.

Moreover, the writer also found three functions of vague language that were often used in Thejakartapost.com, namely giving the right amount of information, filling in lexical gaps of uncertainty, and self-protection. First, the function of giving the right amount of information; it used since the reporters just shared the right number of information although the exact number was not available. Second, filling in lexical gaps of uncertainty; it used since the reporters wanted to cover the imprecise information with another word, and generalized word that was difficult to identify. Last, self-protection; it is used since the reporters wanted to protect, and hedge their statements from imprecise information. Since this news website should supply the news eventually 24 hours a day, the use of vague language would be the best choice in presenting information accurately, if the accurate information was not available.[rgt]

\section{REFERENCES}

Bajri, I. A. (2016). Discourse Analysis on Significant Usage of Vague Language in Edward Albee's The Zoo Story. European Centre for Research and Training and Development UK.

Bakema, M., Constanza, P., Philip M. (2018). Analyzing the Social Lead-Up to a Human-Induced Disaster: The Gas Extraction-Earthquake Nexus in 
Groningen, the Netherlands. Sustainability, 10(10). https://doi.org/ $10.3390 /$ su10103621

Carter, R \& Mcarthy, M. (2006). Cambridge Grammar of English: A Comprehensive Guide. Cambridge University Press.

Creswell, J.W. (2009). Research Design: Qualitative, Quantitative, and Mixed Methods Approaches. Sage Publication.

Channell, J. (1994). Vague Language. Oxford University Press.

Cutting, J. (2007). Vague Language Explored. Palgrave Macmillan.

Handayani, Nur Vita. (2015). The Use of Expressive Speech Acts in Hannah $\begin{array}{llll}\text { Montana Session } & \text { 1. Register, } & \text { 89-112. }\end{array}$ https://doi.org/10.18326/rgt.v8i1.99-112

Jaufillaili, J., Sujatna, E.T., Indira, D., \& Indrayani, L. M. (2017). Vague Languages Implied through Disparagement Functions in Comic Strips. The Southeast Asian Journal of English Language Studies, 23(4), 66-76. https://doi.org/10.17576/3l-2017-2304-06

Khalil, H.H. (2017). A Pragmatic Analysis of Vague Language in the News Articles on the Iraqi Security Crisis. Theory and Practice in Language Studies, Vol. 7, No. 5.

Lambert, V.A., \& Clinton, E.L. (2012). Qualitative Descriptive Research: An Acceptable Design. Pacific Rim International Journal of Nursing Research, 16 (4), 255-256.

Miles, M.B., A. Michael, H., Johnny, S. (2014). Qualitative Data Analysis, A Methods Sourcebook, Edition 3. Sage Publication.

Newman, N., Richard, F., Antonis, K., David, A.L.L., Rasmus, K.N. (2017). Reuters Institute Digital News Report 2017. Reuters Institute for the Study of Journalism, Unversity of Oxford.

Ozturk Tasci, F. \& Oguz Unver, A. (2017). Broad-Based Participatory Inquiry into the Definition and Scope of Disaster. Journal of Education in Science, Environment and Health (JESEH), 3(2), 165-182.

Pan, W. (2012). An Analysis of Vagueness in English News from Grice's Cooperative Principles. Theory and Practice in Language Studies, Vol. 2, No. 12.

Pinar, A. (2017). What is Secondary School Students' Awareness on Disaster? A Case Study. Review of International Geographical Education Online (RIGEO), 7 (3), 315-331. 
The Jakarta Post Staff. (2019). The Jakarta Post. https://thejakartapost.com.

Urbanova, L. (1999). On Vagueness in Authentic English Conversation. Brno Studies in English 25.

Van Deemter, K. (2010). Not Exactly: In Praise of Vagueness. Oxford University Press.

Wahyuningsih, W. (2014). Vague Languages used in CNN.com. Sarjana Sastra (SS) Thesis, Dian Nuswantoro University, Indonesia.

Yule, G. (1996). Pragmatics. Oxford University Pers.

Zhang, G.Q (2011). Elasticity of Vague Language. Intercultural Pragmatics, 8-4.

Zhang, G.Q (2013). The Impact of Touchy Topics on Vague Language Use. Journal of Asian Pacific Communication 23:1

\section{Data Source References:}

Agence France-Presse. (2018, April 2). At least Four Dead as Cyclone Josie Hits Fiji. The Jakarta Post. https://www.thejakartapost.com/news/ 2018/04/02/at-least-four-dead-as-cyclone-josie-hits-fiji.html.

Agence France-Presse. (2018, May 22). Five Dead in India from Nipah Virus, Dozens Quarantined. The Jakarta Post. https://www.thejakartapost.com/news/2018/05/22/five-dead-in-indiafrom-nipah-virus-dozens-quarantined.html.

Agence France-Presse. (2018, July 29). Powerful Storm Hits Disaster-ravaged Japan. The Jakarta Post. https://www.thejakartapost.com/news/2018/ 07/29/powerful-storm-hits-disaster-ravaged-japan.html.

Agence France-Presse. (2018, July 11). 14 Dead in South Syria Suicide Car Bomb Claimed by IS. The Jakarta Post. https://www.thejakartapost.com/news/2018/07/11/14-dead-in-southsyria-suicide-car-bomb-claimed-by-is.html.

Agence France-Presse. (2018, November 5). Total Disaster' as Italy Storms Kill at least $30 . \quad$ The Jakarta Post. https://www.thejakartapost.com/news/2018/11/05/total-disaster-asitaly-storms-kill-at-least-30.html.

Aqil, A.M.I. (2019, February 20). Explosion at Mall Injures 6 people, Damages 40 Food Counters. The Jakarta Post. https://www.thejakartapost.com/news/2019/02/20/explosion-at-mallinjures-6-people-damages-40-food-counters.html. 
Arbi, I.A. (2018, June 26). Fire Engulfs Densely Populated Area in Central Jakarta. The Jakarta

Post. https://www.thejakartapost.com/news/2018/06/26/fire-engulfs-denselypopulated-area-in-scentral-jakarta.html.

Hussein, S. (2018, June 18). Two Dead As Strong Quake Shakes Japan's Osaka. The Jakarta Post. https://www.thejakartapost.com/news/2018/06/18/twodead-as-strong-quake-shakes-japans-osaka.html.

News Desk, Agence France-Presse. (2018, April 8). New Strikes Pound Syria's Ghouta after Alleged Gas Attack. The Jakarta Post. http://www.thejakartapost.com/news/2018/04/08/new-strikes-poundsyrias-ghouta-after-alleged-gas-attack.html.

News Desk, Agence France-Presse. (2018, May 25). At least 7 Dead in Benghazi Attack: Security Source. The Jakarta Post. https://www.thejakartapost.com/news/2018/05/25/at-least-7-dead-inbenghazi-attack-security-source.html.

News Desk, Agence France-Presse. (2018, August 20). Multiple Quakes Rock Indonesia's Lombok Island, 10 dead. The Jakarta Post. https://www.thejakartapost.com/news/2018/08/20/multiple-quakesrock-indonesias-lombok-island-two-dead.html.

News Desk, Agence France-Presse. (2018, August 31). Conflicts may have Killed 5 Million Children in Africa: Study. The Jakarta Post. https://www.thejakartapost.com/news/2018/08/31/conflicts-may-havekilled-5-million--children-in-africa-study.html.

News Desk, Agence France-Presse. (2018, September 20). 3 Dead, 10 Homes Buried in Philippine Monsoon Landslide. The Jakarta Post. https://www.thejakartapost.com/news/2018/09/20/3-dead-10-homesburied-in-philippine-monsoon-landslide.html.

News Desk, Agence France-Presse. (2018, October 26). Jordan Flood Death Toll Rises to 20, most of Them School Pupils. The Jakarta Post. https://www.thejakartapost.com/news/2018/10/26/jordan-flood-deathtoll-rises-to-20-most-of-them-school-pupils.html.

News Desk, Agence France-Presse. (2018, November 12). US Fighter Jet Crashes Off Japan's Okinawa. The Jakarta Post. https://www.thejakartapost.com/news/2018/11/12/us-fighter-jetcrashes-off-japans-okinawa.html.

News Desk, Agence France-Presse. (2018, December 24). Thousands Evacuated After 'Loud Crack' in Sydney Tower. The Jakarta Post. 
https://www.thejakartapost.com/news/2018/12/24/thousandsevacuated-after-loud-crack-in-sydney-tower.html.

News Desk, The Jakarta Post. (2019, January 22). Tornado Destroys Kiosks, Topples Poles in Bekasi. The Jakarta Post. https://www.thejakartapost.com/news/2019/01/22/tornado-destroyskiosks-topples-poles-in-bekasi.html.

News Desk, Agence France-Presse. (2019, January 8). One Dead in Oil Tanker Blaze Off Hong Kong. The Jakarta Post. https://www.thejakartapost.com/news/2019/01/08/one-dead-in-oiltanker-blaze-off-hong-kong.html.

News Desk, Agence France-Presse. (2019, February 8). Hundreds of Thousands' of Cattle Feared Dead after Australia Floods. The Jakarta Post. https://www.thejakartapost.com/news/2019/02/08/hundreds-ofthousands-of-cattle-feared-dead-after-australia-floods.html.

News Desk, The Jakarta Post. (2019, March 11). Fishing Vessel Catches Fire in Muara Angke. The Jakarta Post. https://www.thejakartapost.com/news/2019/03/11/fishing-vesselcatches-fire-in-muara angke.html.

Nugraha, P \& Kharishar, K. (2019, March 17). Malaysian Tourist among Killed in Earthquake-triggered Landslide on Lombok. The Jakarta Post. https://www.thejakartapost.com/news/2019/03/17/tourists-killedinjured-by-earthquake-triggered-landslide-on-lombok.html.

Pearl, H. (2018, December 24). 'Everything's gone: Indonesian Villagers Recount Tsunami Horror. The Jakarta Post. https://www.thejakartapost.com/news/2018/12/24/everythings-goneindonesian-villagers-recount-tsunami-horror.html.

Rahman, R. (2018, October 29). Dozens Gather in Lion Air Crash Crisis Center to Report on Family Members. The Jakarta Post. https://www.thejakartapost.com/news/2018/10/29/dozens-gather-inlion-air-crash-crisis-center-to-report-on-family-members.html.

Sufa, T. (2018, September 12). House Fire Kills Three Children in Bogor. The Jakarta Post. https://www.thejakartapost.com/news/2018/09/12/housefire-kills-three-children-in-bogor.html. 